\title{
Shade-Dwelling Corals of the Great Barrier Reef
}

\author{
Zena D. Dinesen* \\ Department of Marine Biology, James Cook University, Townsville, Queensland 481 1, Australia
}

\begin{abstract}
Shade-dwelling corals were studied from 127 caves, tunnels, and overhangs from a variety of reefs within the Great Barrier Reef Province. Over 3,000 coral colonies were recorded from these shaded habitats, and more than 150 species, mostly hermatypic, were represented. Three groups of shade-dwelling corals are tentatively distinguished: generally skiophilous (shade-loving) corals, found both in deep water and in shallow but shaded conditions; preferentially cavernicolous corals, growing mostly in shallow, shaded habitats; and shade-tolerant corals, common also in better illuminated parts of the reef, but tolerant of a wide range of conditions. Hermatypic shade-dwelling corals usually have thin, flattened growth forms, and the coralla are generally small, suggesting that low light intensity is restricting both the shape and size of colonies. Apart from an abundance of ahermatypic corals on the ceilings of some cavities, particular faunal zones were not detected in different sectors of cavities or at different irradiance levels. This lack of zonation is attributed principally to 2 factors. Firstly, the coral fauna represents only a well shaded but not 'obscure' (dark) aspect of skiophilous communities; secondly, ahermatypic corals were not found in conditions darker than those tolerated by some hermatypic species.
\end{abstract}

\section{INTRODUCTION}

Recent workers (Hartman and Goreau, 1970; Jackson et al., 1971; Jaubert and Vasseur, 1974; Bonem, 1977; Vasseur, 1977) have emphasized the significance, within the coral reef framework, of shaded environments which offer skiophilous organisms an important refuge from competition with faster growing species of the 'open' reef. Shaded habitats may contain a wide range of sessile cryptic organisms, including sponges, algae, coelenterates, brachiopods, bryozoans, serpulid worms, encrusting foraminiferans, ascidians, and bivalve molluscs (Laborel, 1960; Pérès and Picard, 1964; Vacelet, 1967a, b; Hartman and Goreau, 1970; Jackson et al., 1971; Pouliquen, 1971; Vasseur, 1974, 1977; Bonem, 1977; Cuffey and Fonda, 1977; Logan, 1977). These organisms are distributed primarily according to irradiance levels, although water movement may also influence their distribution.

Some components of shallow, cryptic communities also occur in deep water. For instance, bathyal sponges have been found in dark caves in the Mediterranean Sea (Pouliquen, 1969), and similarities between caver-

\footnotetext{
- Present address: Australian Institute of Marine Science, P.M.B. No. 3, M.S.O. Townsville, Queensland 4810, Australia

(c) Inter-Research/Printed in F. R. Germany
}

nicolous and bathyal sponge faunas have been noted at Madagascar (Vacelet and Vasseur, 1977). The emergence of various sponges (including sclerosponges) and brachiopods from shaded habitats with increasing depth has also been observed (Hartman, 1973, 1977; Noble et al., 1976; Logan, 1977). However, the cave-dwelling fauna is not only representative of a deep water fauna displaced into shallow, shaded environments. For example, Vasseur (1974) has reported that some pharetronid sponges are strictly cavernicolous.

Despite the increasing attention being focused on shaded reef habitats, little information has been collected on the cave-dwelling scleractinian fauna of Indo-Pacific reefs. The only detailed records are from the southwest Indian Ocean (Jaubert and Vasseur, 1974; Vasseur, 1974, 1977).

From Madagascar, Jaubert and Vasseur (1974) described skiophilous communities from a wide range of shaded and dark reef cavities. Three basic community types have been defined, according to irradiance levels, and sometimes hydrodynamic factors (Vasseur, 1974). Hermatypic corals, occurring at 2.0 to $8.0 \%$ subsurface irradiance, are characteristic of a better illuminated aspect dominated by algae. Ahermatypic species are notable in some shaded 'animal-dominant' facies. Species of Dendrophyllia and Tubastraea are 
found at 0.5 to $4.0 \%$ subsurface irradiance (often $>1.0 \%$ ), while other ahermatypes (species of Phyllangia, Culicia, and Balanophyllia) occur at slightly lower irradiance levels $(<0.1 \%$ subsurface light).The 'exclusively animal' biocoenosis, confined to darker conditions, is characterized by sponges, and is apparently devoid of corals.

As part of a research programme on coral distribution patterns, the author has investigated shade-dwelling scleractinians of the Great Barrier Reef (G.B.R.). This study revealed definite regional differences in the shade-dwelling coral fauna, with cavities in the southern part of the G.B.R. tending to have an impoverished coral fauna compared with that recorded further north. These regional variations are discussed elsewhere (Dinesen, 1982). This paper investigates the nature of the shade-dwelling coral fauna, to determine whether it is basically cavernicolous, or if it has closer affinities with assemblages from deep water, or from shallow, 'open' reef areas. The distribution and zonation of coral species within cavities and according to irradiance levels are examined, and modifications of growth form and other adaptive strategies of shade-dwelling corals, are discussed.

\section{METHODS}

\section{Field Methods}

Sampling localities represent a wide range of reef types from various sectors of the G.B.R. In the Lizard Island region $\left(14^{\circ}-15^{\circ} \mathrm{S}_{i}\right.$ Fig. 1$), 100$ reef cavities were investigated. Study sites included the fringing reefs and lagoon of the Lizard Island Group; outer slope, reef channel, and back reef areas of 5 outer barrier reefs (Jewell, Carter, Yonge, No Name, and South Ribbon Reefs); and North Direction Island, Eyrie, and MacGillivray Reefs. Two cavities were studied at Keeper Reef $\left(18^{\circ} 45^{\prime} \mathrm{S}, 147^{\circ} 15^{\prime} \mathrm{E}\right)$, and a further 25 at Heron, Wistari, and Wilson Reefs in the Capricorn Group (around

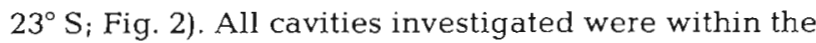
reef slope in a depth range of 4 to $21 \mathrm{~m}$ (approximately below low water datum).

For every coral in each cavity were recorded its identity, colony size and shape, position within the cavity, and the irradiance level at which it occurred.

Colony size was determined from maximum length and maximum width perpendicular to the length (measured to the nearest $\mathrm{cm}$ ). Since most colonies were rather flat, measurements in 2 dimensions were considered adequate. The overall growth form was recorded, and any remarkable growth modifications noted.

To expedite recording the locations of coral colonies, each cavity was treated as a theoretical cube, with ceiling, back wall, floor, and 2 side walls. The position of a colony on one of these surfaces was further defined with respect to its proximity to the aperture. Although cavity shape did not always conform to the theoretical cube, the data indicate possible preferences of species for growing on certain cavity surfaces.

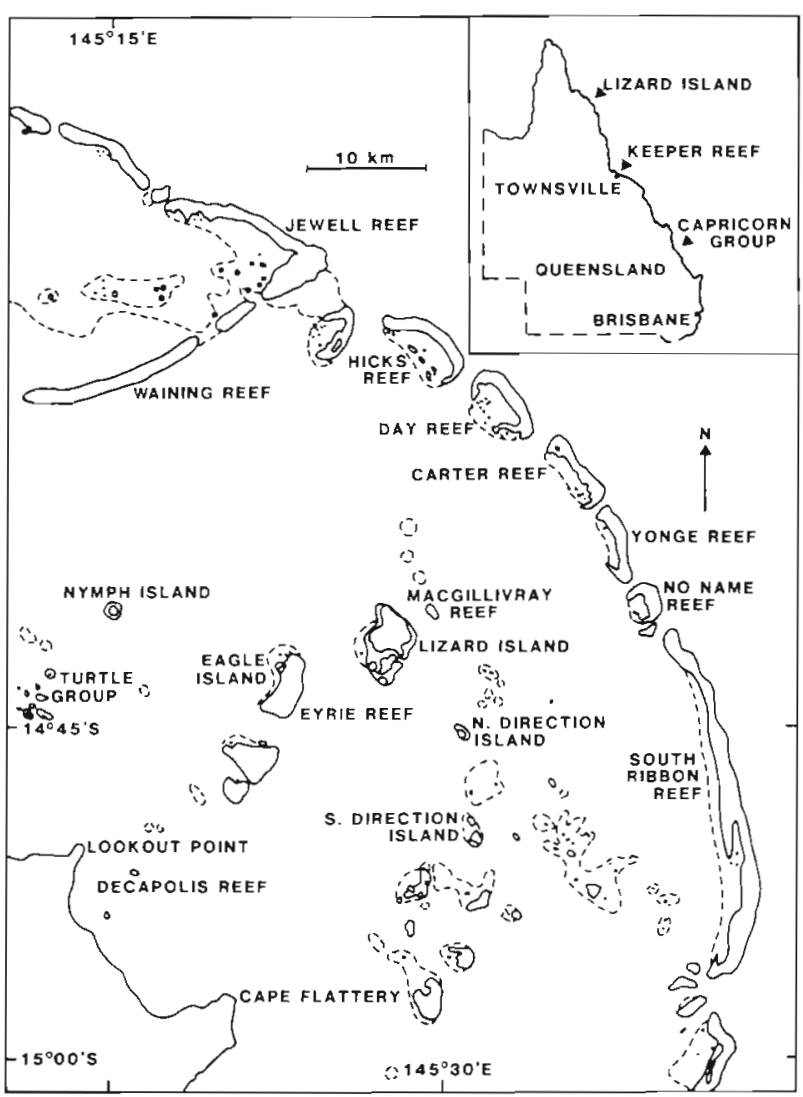

Fig. 1. Reefs in Lizard Island region. Sampling localities given in text. Inset of Queensland coast indicates general locations of study areas

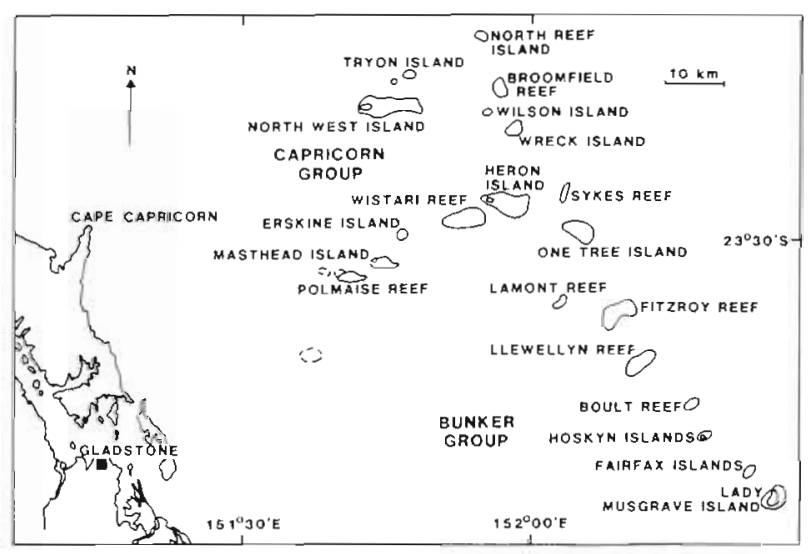

Fig. 2. Reefs in Capricorn region. Sampling localities given in text 
Irradiance readings were taken with a Gossen Lunasix-3 lightmeter. Similar equipment has been used in studies of coral calcification and photosynthetic carbon fixation (Barnes and Taylor, 1973). The range of sensitivity is 0.17 to 350,000 lux ( $1 \mathrm{Klux}=$ $19.5 \mu$ Einsteins $\mathrm{m}^{-2} \mathrm{~s}^{-1}=4.27$ watts $\mathrm{m}^{-2}$, surface solar irradiance $[400$ to $700 \mathrm{~nm}])$. The equipment is designed so that once a reading is taken, the meter can be turned off, but the reading is retained on the scale. Thus records could be taken with the meter held at arm's length to reduce the effect of shadow caused by the observer. Some cavities were too small for a diver to enter to obtain incident light measurements, thus measurements were restricted to reflected light (less than the amount of incident light). Light readings taken for individual corals were expressed as a percentage of the mean subsurface irradiance falling on a horizontal plane (the mean calculated from readings taken before and after the dive).

These light recordings were not expected to measure the amount of light available for photosynthesis. They were intended only as a general, comparative guide to the light levels at which coral species were growing. Some of the variations in light availability (due, for example, to varying cloud cover, albedo, and water turbidity) have been accounted for by relating the measurements to subsurface readings. But since light readings were not continuous, measurements did not account for variation in irradiance distribution as affected by reef topography and solar altitude.

Specimens not identifiable in the field were removed for laboratory examination. Wherever possible, material was identified to species, but some small specimens could not be identified beyond genus or family level. Montipora and Porites (Synaraea) have been given species numbers only. Tubastraea and Dendrophyllia (except $D$. micrantha) were also problematic, as they occurred in large numbers in some cavities, and their similar appearance suggested they belonged to the one species. These ahermaytpes are collectively referred to as 'Tubastraea cf. aurea', but this category also includes $T$. diaphana, $T$. coccinea, $D$. fistula, and D. arbuscula.

\section{Analytical Methods}

Chi-squared contingency tests were used to test for significant differences in the distribution of species within cavities. The following combinations were tested: (1) back wall vs. ceiling vs. floor vs. the 2 side walls; (2) back wall + ceiling (presumably the darkest areas) vs. other parts of cavities; (3) omitting records from the floor, since a sandy substrate might reduce the number of corals found here. The same statistic was applied to test whether these species occurred more often, or less frequently, at cavity apertures.

Multiple range tests were used to compare mean irradiance records for shade-dwelling coral species, and mean values for maximum colony length, and maximum colony area. The test used was Modified Least Significant Difference, a test exact for unequal group sizes, available with the SPSS package (Nie et al., 1975). To investigate the relationship, if any, between colony size and irradiance, simple regressions were carried out (again using SPSS) for both maximum colony length and maximum colony area with irradiance records

Analyses were performed only for the more frequently encountered corals, i. e. those with 15 or more records. Data for distribution on cavity surfaces, irradiance levels, colony size, and growth forms of hermatypes, are presented only for these more common corals. With the exception of young Fungia and young pectiniid, systematic categories higher than species level have not been considered.

\section{RESULTS}

\section{Types of Cavities}

The study areas on the G.B.R., though affording numerous well shaded recesses and small caves, did not support a system of reef cavities comparable either in size or complexity to the Madagascan structures described by Jaubert and Vaseur (1974). Only 3 basic structures were distinguished here: true caves (well enclosed cavities with distinct side walls), overhangs (shaded recesses, but with one or both side walls, and/ or the floor lacking), and tunnels (open-ended caves). These are referred to collectively as cavities. The cavities encountered were shaded or gloomy; few could be termed 'semi-obscure' (sensu Laborel, 1960), and none was completely 'obscure'. However, various studies (e. g. Jackson et al., 1971; Jaubert and Vasseur, 1974; Vasseur, 1974, 1977; Jackson, 1977) have shown that even small habitats, such as the undersides of coral blocks or foliose corals, are sufficiently shaded to support communities substantially different from those of the 'open' reef. Despite some variations in communities from different reef structures, many skiophilous communities have a common biocoenotic basis which is determined not so much by the size of the habitat, but rather by the conditions of illumination (and sometimes hydrodynamics) which prevail. Therefore, although many of the cavities investigated in this study were comparatively small (often $<2 \mathrm{~m}$ in largest dimension), they could nevertheless support communities which are basically skiophilous in nature. 
Table 1. Tentative tabulation of generally skiophilous, preferentially cavernicolous, and shade-tolerant coral species

\begin{tabular}{|lcl|}
\hline Generally skiophilous species & Preferentially cavernicolous species & Porites australiensis \\
Leptoseris hawaiiensis & Stylocoeniella armata & Porites lichen \\
Leptoseris mycetoseroides & Stylocoeniella guentheri & Favites risselli \\
Leptoseris scabra & Psammocora profundacella & Goniastrea palauensis \\
Pachyseris speciosa & Psammacora superficialis & Goniastrea pectinata \\
Scolymia cf. vitiensis & Pavona cf. explanulata & Cyphastrea japonica \\
Echinophyllia aspera & Lithophyllon cf. edwardsi & Cyphastrea microphthalma \\
Echinophyllia orpheensis & Physogyra lichtensteini & Cyphastrea serailia \\
Oxypora lacera & & Echinopora lamellosa \\
Mycedium elephantotus & Shade-tolerant species & Galaxea cf. astreata \\
Tubastraea cf. aurea & Seriatopora hystrix & Merulina ampliata \\
? Some Montipora species & Pavona varians & Lobophyllia hemprichii \\
& Coscinaraea columna & ? Some Montipora species \\
& & ? Some Fungia species \\
\hline
\end{tabular}

\section{Nature of the Shade-Dwelling Coral Fauna}

The coral assemblages investigated are collectively referred to as shade-dwelling, but from this study one may tentatively distinguish among the fauna 3 basic types of shade-dwelling corals. These are: generally skiophilous corals, which occur both in deeper water and in shaded areas in shallower water; preferentially cavernicolous corals, which appear to grow mostly in cavities, being uncommon in 'open' reef areas; and shade-tolerant corals, common in well illuminated reef areas but able to adapt to shaded conditions.

A full list of species recorded in this study is given in the Appendix. In Table 1, those most commonly encountered have tentatively been grouped into 1 of the above 3 categories. In compiling this table, the fauna recorded has been compared with earlier IndoPacific records for corals occurring in deep water, shaded, or well illuminated, 'open' reef habitats. The most detailed accounts from deep water dredge samples are those of Bassett-Smith (1890) from the China Sea, Vaughan (1907) from Hawaii, and Wells (1954) from the Marshall Islands. Additional information is available from Quelch (1886), Gardiner (1897, 1898, 1904, 1905), Horst $(1921,1922)$, and from Rosen's (1971) generic records. SCUBA collections, though relatively shallow, may also indicate species growing in low light conditions, below the optimum range of most hermatypic corals (Barnes et al., 1971; Dinesen, 1977; Pichon, 1978). Records of cavity-dwelling corals are available from Madagascar (Jaubert and Vasseur, 1974; Vasseur, 1974, 1977), and some habitat data are given by Veron and Pichon $(1976,1980)$ and Veron et al. (1977). Data for corals from shallow, 'open' reef habitats have been obtained from Wells $(1954,1955)$, Veron and Pichon (1976, 1980), Veron et al. (1977), Pichon (1978), and numerous own observations.

It is unlikely that any one species will fall exclusively into a single category. Furthermore, lack of records from deep water for some species may indicate inadequate sampling, rather than absence of these species from deeper zones. Diver surveys of shaded habitats are restricted to comparatively shallow water, and dredge samples from deeper water are likely to bring up only non-cryptic species. Therefore the possible existence of a deep water cavernicolous fauna, distinct from that found in shallower water, is not considered here.

Generally skiophilous corals: These corals may actually be photophobic, unable to adapt to well illuminated conditions. They are probably confined to shaded areas in shallow water because of competitive exclusion by faster growing reef organisms. Pachyseris, Echinophyllia, Oxpora, and especially Leptoseris, are conspicuous in this group.

Hartman and Goreau (1970) noted that certain skiophilous organisms (such as sclerosponges) are more successful in shallower, shaded environments than in 'open' areas in deeper water, probably because of the greater availability of food in shallower water. Logan (1977) found that the distribution of cryptic brachiopods reflects also a trend of greater feeding efficiency with increasing depth, suggesting a diminished food supply in deeper water. Whether generally skiophilous scleractinians commonly found in deeper water are actually more successful in shallow, shaded environments has yet to be determined.

Preferentially cavernicolous corals: Shade-dwelling corals, such as Stylocoeniella guentheri, S. armata, and Physogyra lichtensteini, do seem to prefer shallow but shaded habitats. The other species in the category, while commonly encountered in cavities, have not been notable either in deep water collections, or in 'open' reef areas.

Shade-tolerant corals: Many cavity-dwelling species frequently occur in many reef habitats, and can apparently adapt to a wide range of conditions. Notable in this group are Pavona varians, Seriatopora 
hystrix, Coscinaraea columna, Goniastrea pectinata, and species of Porites and Cyphastrea. Most of these probably seldom invade the deeper hermatypic zones characterized by Leptoseris and pectiniids.

Rarely recorded species: About half of the species recorded were rarely encountered (see Appendix), and then principally at cavity apertures, suggesting that they were 'accidental' among the cavity fauna. Thus various species of Acropora, Goniopora, Turbinaria, certain faviids, and some Fungia species, more common on the 'open' reef, are not considered typical of the shade-dwelling fauna. Other corals, such as Blastomussa, Cynarina, and Alveopora, have been noted in deep water or shaded habitats (Bassett-Smith, 1890; Wells, 1954; Rosen, 1971; Wijsman-Best, 1973; Pichon, 1978; Veron and Pichon, 1980); and the small number of records here is probably a reflection of their uncommonness on the G.B.R. Other corals, such as Porites (Synaraea), of which there are comparatively few records in the systematic and ecological literature, may or may not show a preference for shaded environments.

Ahermatypic vs, hermatypiccomposition of the fauna: The ahermatypic genera recorded have all been found at depths far exceeding the range of hermatypic corals (Vaughan, 1907; Vaughan and Wells, 1943; Wells, 1956). In reef regions, ahermatypic zones bathymetrically succeed hermatypic zones, with a transitional region in which Leptoseris is the only notable hermatype (Vaughan, 1907; Wells, 1954). Jaubert and Vasseur (1974) and Vasseur (1974) reported 5 ahermatypic genera from Madagascan caves. It is surprising that Balanophyllia was so rarely encountered here, and that the rhizangiid genera, not uncommon in many reef areas (Vaughan and Wells, 1943; Wells, 1956), were not recorded at all.

Surprisingly, apart from the sporadically abundant Tubastraea cf. aurea, ahermatypic corals were not con-

Table 2. Growth forms usually adopted by common shade-dwelling hermatypic species

\begin{tabular}{|c|c|}
\hline Species & Growth form \\
\hline $\begin{array}{l}\text { Stylocoeniella armata } \\
\text { Stylocoeniella guentheri } \\
\text { Psammocora profundacella } \\
\text { Psammocora superficialis } \\
\text { Seriatopora hystrix } \\
\text { Montipora sp. } 1 \\
\text { Montipora sp. } 2 \\
\text { Montipora sp. } 8 \\
\text { Pavona cf. explanulata } \\
\text { Pavona varians } \\
\text { Leptoseris hawailensis } \\
\text { Leptoseris mycetoseroides } \\
\text { Leptoseris scabra } \\
\text { Pachyseris speciosa } \\
\text { Coscinaraea columna } \\
\text { Lithophyllon cf. edwardsi } \\
\text { Young Fungia } \\
\text { Porites australiensis } \\
\text { Porites lichen } \\
\text { Favites russelli } \\
\text { Goniastrea palauensis } \\
\text { Goniastrea pectinata } \\
\text { Cyphastrea japonica } \\
\text { Cyphastrea microphthalma } \\
\text { Cyphastrea serailia } \\
\text { Echinopora lamellosa } \\
\text { Galaxea cf. astreata } \\
\text { Merulina ampliata } \\
\text { Scolymia cf. vitiensis } \\
\text { Lobophyllia hemprichii } \\
\text { Echinophyllia aspera } \\
\text { Echinophyllia orpheensis } \\
\text { Oxypora lacera } \\
\text { Mycedium elephantotus } \\
\text { Young pectiniid } \\
\text { Physogyra lichtensteini }\end{array}$ & $\begin{array}{l}\text { Encrusting } \\
\text { Encrusting } \\
\text { Encrusting } \\
\text { Encrusting } \\
\text { Branching } \\
\text { Encrusting or laminar } \\
\text { Encrusting } \\
\text { Encrusting } \\
\text { Encrusting or laminar } \\
\text { Encrusting } \\
\text { Encrusting or laminar } \\
\text { Encrusting } \\
\text { Encrusting or laminar } \\
\text { Encrusting, laminar, or cup-shaped } \\
\text { Encrusting, submassive, or laminar } \\
\text { Encrusting } \\
\text { Attached solitary form } \\
\text { Encrusting or submassive } \\
\text { Encrusting } \\
\text { Encrusting } \\
\text { Encrusting } \\
\text { Encrusting or submassive } \\
\text { Encrusting } \\
\text { Encrusting } \\
\text { Encrusting } \\
\text { Encrusting or laminar } \\
\text { Encrusting } \\
\text { Encrusting or laminar } \\
\text { Attached solitary form } \\
\text { Phaceloid or flabellate } \\
\text { Encrusting or laminar } \\
\text { Encrusting } \\
\text { Encrusting or laminar } \\
\text { Laminar } \\
\text { Encrusting or cup-shaped } \\
\text { Encrusting }\end{array}$ \\
\hline
\end{tabular}


spicuous among the cavity-dwelling fauna, while hermatypic species were frequently encountered. Admittedly, Tubastraea and the notably skiophilous hermatypic genus Leptoseris (and their respective families) are numerically the most important. However, a wide range of hermatypic species is reprensented in the records, particularly among the Faviidae, Acroporidae, and Poritidae. Notable are Porites, Montipora, and Cyphastrea, widely occurring genera which have not been conspicuous in records of deep water or shade-dwelling corals. However, definite regional differences were found in the shade-dwelling coral fauna (see Appendix and Dinesen, 1982); if field work had been concentrated in the Capricorn Group instead of further north, the records would have had a different emphasis.

\section{Growth Form}

The colony shapes usually adopted by common shade-dwelling hermatypes are indicated in Table 2. These forms are predominantly encrusting, or laminar (i.e. flattened plates), occasionally in overlapping series. Of corals able to produce laminar shapes, Pachyseris speciosa, Pavona cf. explanulata, Echinopora lamellosa, and Merulina ampliata were equally often encrusting or laminar, but the Leptoseris were frequently fully encrusting, or encrusting with free margins only.

Corals tending to form submassive or massive colonies in brighter conditions (e.g. the faviids and Porites) were usually restricted to rather flat, encrusting shapes. Cyphastrea japonica never produced extensively branching coralla, and the branching species Seriatopora hystrix always had thin, widely spaced branches.

According to Roos (1967) and Jaubert (1977), plateshaped corals in low light intensities orientate themselves according to irradiance distribution. This response was often observed among laminar shadedwelling corals, especially Pavona cf. explanulata, such forms having plates directed towards the cavity opening.

Coral species growing in deeper water and hence at lower light intensities may adopt a flatter, more plateshaped morphology than their shallow-water conspecifics (Goreau, 1963; Roos, 1967; Barnes, 1973; Barnes and Taylor, 1973; Dustan, 1975; Graus and Macintyre, 1976; Graus, 1977; Jaubert, 1977). In the cavities, however, encrusting forms were much more common than plate-shaped ones. Jaubert and Vasseur (1974) found encrusting but not laminar hermatypic corals in shaded habitats at Madagascar.
Corallite arrangement is apparently affected by reduced light intensity. The most obvious modification observed was that many species often had widely spaced corallites. This was noted in Leptoseris and Echinophyllia, but was most conspicuous in species of Porites, Galaxea, and Cyphastrea, which usually have more crowded corallites in coralla from unshaded reef areas. The most extreme example of reduced corallite number was a specimen of Montipora sp., about $10 \mathrm{~cm}$ across, in which there were only 2 corallites. Other modifications were observed, such as a highly vesicular coenosteum in Cyphastrea and Galaxea cf. astreata, and an almost complete flattening of the collines in some Pachyseris speciosa.

Greater spacing of corallites in colonies from low light environments has been noted by several other workers. A tendency for corals (especially faviids) to have fewer corallites per unit area with increasing depth has been observed (Scatterday, 1974; WijsmanBest, 1974; Lasker, 1977; Highsmith, 1979). This may also occur on shaded parts of otherwise normal coral colonies (Kawaguti, 1937). Veron et al. (1977) and Veron and Pichon (1980) noted that some species from poorly illuminated biotopes have, additionally, a typically blistered, vesicular coenosteum.

In contrast to hermatypic species, the growth forms of ahermatypic corals (usually restricted to shaded conditions in shallow water) showed little variation. The Balanophyllia specimens were of course solitary, and the larger $D$. micrantha were typically dendroid. Smaller Dendrophyllia species and many Tubastraea specimens consisted of only 1 or 2 corallites.

\section{Distribution of Species on Cavity Surfaces}

For Tubastraea cf. aurea, all chi-squared tests for location on cavity surfaces were highly significant ( $p=<0.001)$, demonstrating that the ahermatype grows preferentially and almost exclusively on cavity ceilings. The illustrations of Jaubert and Vasseur (1974) and Vasseur (1974) similarly indicate that Dendrophyllia and Tubastraea grow in abundance on the upper horizontal surfaces of overhangs. No other significant differences were found, even at the $10 \%$ significance level. This is perhaps surprising, since several other species (especially Leptoseris mycetoseroides, L. hawailensis, Physogyra lichtensteini) appeared to grow preferentially on certain surfaces in cavities.

In terms of proximity to cavity aperture, for most commonly recorded species, records from the aperture were between $25 \%$ and $50 \%$ of the total records, suggesting no particular preferences. Fewer than $20 \%$ of specimens were recorded at cavity apertures for 
Leptoseris hawailensis, L. scabra, Lithophyllon cf. edwardsi, and young pectiniids. Only Porites lichen and Mycedium elephantotus were found most often at the aperture ( $>80 \%$ total records at aperture). In no instances, however, were significant differences found for occurrence at, or away from, cavity apertures.

\section{Irradiance Records}

Mean, minimum, and maximum irradiance records are given in Table 3. Although the light measurements of Jaubert and Vasseur (1974) were of incident light over a wider spectral range, these were also expressed as a percentage of subsurface recordings, and some comparisons may be made.

My own figures seem comparatively low, which may

Table 3. Irradiance records for common shade-dwelling corals

\begin{tabular}{|llll|}
\multicolumn{1}{c}{ Species } & \multicolumn{3}{c}{ \% Subsurface irradiance } \\
\cline { 3 - 4 } & Mean & Minimum & Maximum \\
\hline Leptoseris hawaiiensis & 0.095 & 0.005 & 0.800 \\
Tubastraea cf. aurea & 0.108 & 0.002 & 0.800 \\
Leptoseris scabra & 0.112 & 0.003 & 0.800 \\
Young Fungia & 0.133 & 0.006 & 0.580 \\
Cyphastrea japonica & 0.142 & 0.013 & 0.800 \\
Leptoseris mycetoseroides & 0.143 & 0.009 & 0.800 \\
Echinophyllia aspera & 0.151 & 0.013 & 1.140 \\
Stylocoeniella armata & 0.157 & 0.025 & 1.170 \\
Favites russelli & 0.158 & 0.020 & 0.590 \\
Psammocora superficialis & 0.162 & 0.003 & 1.140 \\
Stylocoeniella guentheri & 0.170 & 0.003 & 2.300 \\
Echinopora lamellosa & 0.190 & 0.018 & 0.580 \\
Young pectiniid & 0.195 & 0.009 & 1.600 \\
Pachyseris speciosa & 0.203 & 0.003 & 1.670 \\
Cyphastrea serailia & 0.211 & 0.025 & 1.170 \\
Physogyra lichtensteini & 0.215 & 0.003 & 1.600 \\
Pavona varians & 0.219 & 0.003 & 1.600 \\
Pavona cf. explanulata & 0.219 & 0.013 & 1.600 \\
Lithophyllon cf. edwardsi & 0.220 & 0.009 & 4.000 \\
Montipora sp. 1 & 0.221 & 0.040 & 1.170 \\
Merulina ampliata & 0.233 & 0.013 & 0.590 \\
Seriatopora hystrix & 0.234 & 0.020 & 1.170 \\
Coscinaraea columna & 0.240 & 0.013 & 1.600 \\
Mycedium elephantotus & 0.244 & 0.006 & 1.600 \\
Montipora sp. 8 & 0.270 & 0.025 & 1.600 \\
Oxypora lacera & 0.293 & 0.030 & 1.670 \\
Goniastrea pectinata & 0.313 & 0.013 & 1.600 \\
Porites australiensis & 0.316 & 0.040 & 1.140 \\
Echinophyllia orpheensis & 0.331 & 0.025 & 3.180 \\
Cyphastrea microphthalma & 0.340 & 0.025 & 4.550 \\
Porites lichen & 0.343 & 0.025 & 2.300 \\
Lobophyllia hemprichii & 0.359 & 0.025 & 3.180 \\
Scolymia cf. vitiensis & 0.390 & 0.020 & 3.180 \\
Goniastrea palauensis & 0.394 & 0.040 & 1.170 \\
Montipora sp. 2 & 0.426 & 0.100 & 1.170 \\
Galaxea cf. astreata & 0.437 & 0.013 & 3.180 \\
Psammocora profundacella & 0.438 & 0.013 & 3.300 \\
& & & \\
\hline
\end{tabular}

be because readings were of reflected, not incident, light. However, the reference measurements taken at Madagascar (Jaubert and Vasseur, 1974, p. 130) were taken over a $24 \mathrm{~h}$ period, while measurements taken in their caves were not. Since their reference measurements included hours of darkness, the in situ records would therefore appear proportionally greater than my own measurements, expressed as a percentage of daytime reference measurements.

Hoek et al. (1978) estimated that corals growing at 80 to $90 \mathrm{~m}$ at Curaçao receive about $0.2 \%$ of surface radiation. They suggested that the lack of corals below this depth was due to a change in substratum rather than to insufficient light. Their report therefore indicates that hermatypic corals are quite capable of growing at light levels below $1.0 \%$ of surface irradiance.

In the upper part of Table 3, with lowest light readings, it is not surprising to find agariciids, Tubastraea and Echinophyllia, since earlier reports have indicated their skiophilous nature. Very low mean irradiance levels were recorded for Leptoseris hawailensis and $L$. scabra. At Hawaii, Vaughan (1907) found that these 2 species extended into far deeper water than other hermatypes, with $L$. scabra most abundant at 48 to $91 \mathrm{~m}$, and L. hawaiiensis common from 48 to $133 \mathrm{~m}$. Rather low mean records were also obtained for several species (e.g. Cyphastrea japonica, C. serailia, Favites russelli) which have not been conspicuous in reports of deep water or skiophilous corals

When mean irradiance readings for these species were compared, no significant differences were found at the $5 \%$ level, either for untransformed or $\log (n+1)$ transformed data. This result is surprising, since analysis of variance (a more powerful test than the multiple range test; Nie et al., 1975) was highly significant ( $p=<0.001$ ), and mean irradiance values at the top of Table 3 are 3 or 4 times lower than those at the bottom of the list. One might have expected corals such as Tubastraea, Leptoseris, and Echinophyllia, noted from considerable depth, to occur at significantly lower light levels than the less skiophilous species.

Jaubert and Vasseur (1974) reported from Madagascar that Tubastraea and Dendrophyllia occur at slightly lower irradiance levels than hermatypic species. Owing to taxonomic problems, Tubastraea and Dendrophyllia were not clearly differentiated in this study; but the mean and minimum light levels recorded for the ahermatypic corals are no lower than those for the more skiophilous hermatypes.

The lack of significant differences between irradiance records for shade-dwelling corals may be explained in terms of 2 factors. Firstly, the corals were growing in a low and limited range of illumination; secondly, no ahermatypic corals occurred in conditions gloomier than those tolerated by hermatypic species. 


\section{Colony Size}

Mean, minimum, and maximum values for maximum colony length are listed in Table 4. Of smallest. size are young or basically solitary forms, and Tubas. traea and Lithophyllon cf. edwardsi, which are often restricted to a small colony size. Although forms frequently growing as plates (Pavona cf. explanulata, Mycedium elephantotus, Pachyseris speciosa) are at the bottom of the table, there is generally little relationship between colony size and growth form.

Previous workers have presented data on coral colony sizes (reviewed by Buddemeier and Kinzie, 1976), but different measurement techniques plus the fact that data concern different (mostly Caribbean) species, preclude satisfactory comparisons. Comparable measurements of maximum colony diameter by Hughes

Table 4. Records of maximum colony length for common shade-dwelling corals

\begin{tabular}{|c|c|c|c|}
\hline \multirow[t]{2}{*}{ Species } & \multicolumn{3}{|c|}{ Maximum colony length $(\mathrm{cm})$} \\
\hline & Mean & Minimum & Maximum \\
\hline Young Fungia & 1.8 & 1.0 & 3.0 \\
\hline Young pectiniid & 2.9 & 1.0 & 12.0 \\
\hline Tubastraea cf. aurea & 2.9 & 1.0 & 8.0 \\
\hline Lithophyllon cf. edwardsi & 3.7 & 2.0 & 8.0 \\
\hline Physogyra lichtensteini & 5.8 & 1.0 & 30.0 \\
\hline Scolymia cf. vitiensis & 6.1 & 2.0 & 12.0 \\
\hline Echinophyllia orpheensis & 6.1 & 1.0 & 17.0 \\
\hline Stylocoeniella armata & 6.7 & 2.0 & 17.0 \\
\hline Leptoseris scabra & 6.7 & 1.0 & 27.0 \\
\hline Galaxeacf. astreata & 8.1 & 2.0 & 37.0 \\
\hline Goniastrea pectinata & 9.7 & 2.0 & 40.0 \\
\hline Goniastrea palauensis & 10.1 & 4.0 & 29.0 \\
\hline Echinophyllia aspera & 10.1 & 2.0 & 85.0 \\
\hline Cyphastrea microphthalma & 10.2 & 2.0 & 32.0 \\
\hline Seriatopora hystrix & 10.4 & 3.0 & 40.0 \\
\hline Favites russelli & 10.5 & 4.0 & 36.0 \\
\hline Lobophyllia hemprichii & 10.6 & 4.0 & 65.0 \\
\hline Porites lichen & 10.7 & 2.0 & 40.0 \\
\hline Stylocoeniella guentheri & 10.8 & 2.0 & 58.0 \\
\hline Oxypora lacera & 10.9 & 4.0 & 24.0 \\
\hline Montiporasp. 2 & 11.8 & 4.0 & 27.0 \\
\hline Merulina ampliata & 12.9 & 3.0 & 63.0 \\
\hline Leptoseris hawailensis & 13.0 & 2.0 & 50.0 \\
\hline Psammocora profundacella & 13.5 & 2.0 & 60.0 \\
\hline Cyhastrea serailia & 13.7 & 3.0 & 58.0 \\
\hline Pavona varians & 15.8 & 2.0 & 91.0 \\
\hline Cyphastrea japonica & 16.3 & 2.0 & 48.0 \\
\hline Leptoseris mycetoseroides & 17.3 & 2.0 & 75.0 \\
\hline Echinopora lamellosa & 18.1 & 3.0 & 58.0 \\
\hline Psammocora superficialis & 18.4 & 3.0 & 85.0 \\
\hline Pachyseris speciosa & 21.1 & 1.0 & 120.0 \\
\hline Coscinaraea columna & 21.1 & 3.0 & 73.0 \\
\hline Porites australiensis & 21.1 & 4.0 & 63.0 \\
\hline Montiporasp. 1 & 21.5 & 3.0 & 80.0 \\
\hline Montiporasp. 8 & 24.8 & 3.0 & 100.0 \\
\hline Mycedium elephantotus & 25.4 & 5.0 & 80.0 \\
\hline Pávona cf. explanulata & 30.6 & 2.0 & 140.0 \\
\hline
\end{tabular}

and Jackson (1980) were given in detail only for 1 species. Sheppard's (1980) figures concerned colony area measurements; however, they do suggest that several of the species observed here attain a much larger size in 'open' reef areas. According to the author's own observations on the G.B.R., many shadetolerant species frequently grow much larger in unshaded conditions, e.g. Seriatopora hystrix, Porites lichen, Echinopora lamellosa, Galaxea cf. astreata, Merulina ampliata, and Lobophyllia hemprichii. Other workers (e.g. Loya, 1972) have reported a decrease in colony size with reduced irradiance in deeper water.

Despite the range of measurements, few differences were found between the colony sizes of shade-dwelling corals. Comparison of mean values for maximum colony length showed only that Pavona cf. explanulata (with by far the greatest mean value) was significantly larger ( $\mathrm{p}=<0.05$ ) than the first 9 species in Table 4 (down to Goniastrea pectinata). Comparison of the mean values for maximum area yielded no significant differences between species at the $5 \%$ level.

Significant correlations ( $\mathrm{p}=<0.05$ ) were obtained for only a few species for maximum colony length with irradiance readings, but no correlations were found between maximum colony area and irradiance. The general lack of correlation between colony size and irradiance is presumably because the data here concern small colonies from a fairly low and narrow range of illumination.

\section{GENERAL DISCUSSION}

\section{Adaptive Strategies}

While measurements of light intensity must be treated as an approximate guide only, it is clear that many hermatypic species can occur at very low light intensities. Adaptation of corals to growing in poor illumination has been documented on a between- and a within-species basis (e.g. Kawaguti, 1937; Barnes and Taylor, 1973; Bak, 1976; Wethey and Porter, 1976a, b; Houck et al. 1977; Jaubert, 1977). Intraspecific adaptation in corals living in deep water or shaded habitats is achieved by an increase in the number and size of zooxanthellae, their pigment content and pigment ratios, resulting in greater absorption and more efficient use of radiant energy (Titlyanov et al., 1980; Zvalinskij et al., 1980). Evidence also suggests that even at low light intensities corals can satisfy much or all of their energy requirements from photosynthesis (Wethey and Porter, 1976b; Jaubert, 1977). At subsurface irradiance levels of only a few percent, shadeadapted Synaraea convexa can still maintain a $\mathrm{P} / \mathrm{R}$ ratio of greater than unity (Jaubert, 1977). The species commonly encountered in this study must surely have 
photosynthetic compensation points far lower than corals dwelling in well illuminated parts of the reef, and adaptation must be occurring at a within-species level, for many of these species frequently occur in unshaded environments.

Growth form modifications, especially the wider spacing of corallites, may also be advantageous in poorly illuminated conditions. Scatterday (1974, p. 105) speculated that the increased area of zooxanthellae-studded coenosarc between polyps may better enable the colonies to function in low light'. Lasker (1977) has also suggested (for Montastrea cavernosa) that polyps, having a greater tissue mass per unit area, have higher respiration rates than the coenosarc, thus polyps (unless expanded) will be less efficient photosynthetic surfaces. A decrease in the number of polyps and a greater proportion of zooxanthellae in the coenosarc therefore serve to maximize the use of coenosarc for photosynthesis.

Many shade-dwelling species are small-polyped forms (e.g. Psammocora, Montipora, Cyphastrea, and especially the agariciids). According to Porter (1976), corals with small polyps are unlikely to be efficient at capturing zooplankton, and will not therefore be very heterotrophic in nature. Normally, such corals have a high surface/volume ratio for efficient light interception (Porter, 1976) but this was not the case with the mostly two-dimensional shade-dwelling forms. However, these corals may also feed on suspended particles by using mucus nets and strands. This form of feeding is adopted particularly by agariciids (at least in the Caribbean; Lewis and Price, 1975), and suspended food matter may satisfy a substantial proportion of a coral's daily maintenance requirements (Lewis, 1977).

Although corals are capable of adapting their photosynthetic apparatus to low irradiance levels, and perhaps use alternative food sources, it seems that conditions in shaded habitats are such that these corals must adopt a basically two-dimensional, encrusting or laminar growth form, with generally small and fragile coralla.

Light is not the only factor which may affect colony size. Some workers have proposed that coral growth is determinate and is therefore influenced by the size and age of the colony, although others have suggested that growth may be indeterminate (see review by Buddemeier and Kinzie, 1976; Hughes and Jackson, 1980). Other factors, e.g. lack of nutrients or suitable substrate, or competition for space with other organisms, may also restrict colony size. However, substratum did not generally appear to be limiting; and since many of the cavities investigated were overhangs allowing considerable water movement (Dinesen, 1980a), it seems unlikely that lack of nutrients due to poor water circulation would be restricting coral growth. The rela- tively small size of most cavity-dwelling colonies is therefore attributed to conditions of low irradiance.

\section{Lack of Zonation Within Caves}

Apart from the abundance of Tubastraea cf. aurea on the ceilings of some cavities, definite zones or facies within cavities were not detected in this study. This finding may appear to contradict the reports of Jaubert and Vasseur (1974) and Vasseur (1974) from Madagascar. There are, however, some sound reasons for the general lack of zonation of species on a within-cavity basis reported here. Since this research focused on shade-dwelling scleractinians, which are typical only of certain less 'obscure' (dark) aspects of skiophilous communities, one could not expect to find extensive zonation patterns within cavities and according to irradiance levels. More significantly, in contrast to the patterns found at Madagascar, this study did not reveal obvious differences in the distribution of hermatypic and ahermatypic corals within cavities. Corals such as Balanophyllia and the rhizangiids were rare or absent in the G. B. R. cavities. These corals apparently occur in darker conditions than Tubastraea, Dendrophyllia, and hermatypic species (Jaubert and Vasseur, 1974). Had these more skiophilous corals been notable in shadedwelling assemblages on the G.B.R., a definite ahermatypic aspert might have been detected. At Madagascar, Tubastraea and Dendrophyllia occurred at irradiance levels intermediate between the hermatypic species and the other ahermatypes. In this study no distinct pattern was observed. In the Philippines, the reverse pattern has been observed. In the large Marigondon Cave (Mactan I., Cebu), a zone of Dendrophyllia and Tubastraea occurs on the ceiling (depth $\sim 30 \mathrm{~m}$ ) near the cave aperture. Further back in the cave, in gloomier conditions, the ceiling is covered with numerous Leptoseris cf. scabra (G. Hodgson, M. Ross, pers. comm.). Finally, a much greater variety of skiophilous hermatypes was encountered on the Barrier Reef, than was observed at Madagascar. These factors may account for the general lack of zonation within cavities between hermatypes and ahermatypes according to irradiance levels.

\section{APPENDIX}

\section{List of Scleractinian Corals Recorded from Caves}

Most identifications follow the recent systematic treatments by Veron and Pichon $(1976,1980)$, Veron et al. (1977), and Wallace (1978); for Leptoseris, see Dinesen (1980b). Note that for the species Pavona cf. explanulata, Lithophyllon cf. edwardsi, Leptastrea cf. 
bottae, Galaxea cf. astreata, and Scolymia cf. vitiensis, only the nomenclature, not the identification, is in doubt. For note on Tubastraea cf, aurea refer to 'Methods'.

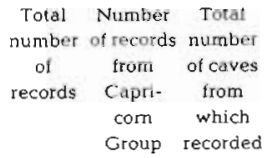

Astrocoeniidae

Stylocoeniella armata (Ehrenberg)

$24 \quad 2 \quad 11$

Stylocoeniella guentheri (Bassett-Smith)

139

Thamnasteriidae

Psammocora digitataMilne-Edwards \& Haime

Psammocora explanulata Horst

Psammocora haimeana Milne-Edwards

\& Haime

psammocora nierstraszi Horst .

Psammocora profundacella Gardiner

Psammocora superficialis Gardiner

Pocilloporidae

Stylophora pistillata (Esper)

Seriatopora hystrix Dana

Pocillopora damicomis (Linnaeus) "

Madracis kirbyi Veron \& Pichon

Acroporidae

Acropora aculeus (Dana)"

Acropora cerealis (Dana)"

Acropora florida (Dana) *

Acropora granulosa (Milne-Edwards

\& Haime) "

Acropora nasuta (Dana) "

Acropora squarrosa (Ehrenberg) "

Acropora spp

Astreopora spp.

Montipora sp. 1

Montipora sp. 2

Montiporasp. 3

Montipora sp. 4

Montipora sp. 5

Montipora sp. 6

Montiporasp. ? $^{\circ}$

Montiporasp. 8

Montiporasp. 9

Montipora sp. $10 \%$

Montipora sp. $11^{*}$

Montiporasp. 12

Montipora sp. 13

Montipora sp. $14{ }^{\prime}$.

Montiporasp. 15

Montiporásp. $16^{\circ}$

Montiporasp. 17

Montipora sp. 18

Montiporasp. 19

Montipora sp. 20

Montiporaspp.

Agariciidae

Pavona decussata (Dana)

Pavona cf explarulata (Lamarck)

pavona maldivensis (Gardiner)"

Pavona minuta Wells. .

Pavona varians Verrill

Pavona venosa (Ehrenberg)

Pavona yabei Pillai \& Scheer ${ }^{*}$

Leptoseris hawaiensis Vaughan

Leptoseris mycetoseroides Wells

Leptoseris glabra Dinesen

Leptoseris scabra Vaughan

Leptoseris spp.

pachyseris rugosa (Lamarck)

Pachyseris speciosa (Dana)

Siderastreidae

Pseudosiderastrea tayamai Yabe \& Sugiyama

Coscinaraea columna (Dana)

Coscinaraea wellsi Veron \& Pichon

$\begin{array}{rrr}1 & 1 & 1 \\ 1 & 11 & 27 \\ 1 & 0 & 1\end{array}$

$0 \quad 56$

Fungiidae

Cycloseris erosa (Döderlein) . .

Cycloseris marginata (Boschma)

Lithophyllon cf. edwardsi (Rousseau)

Fungia (Pleuractis) moluccensis Horst *

Fungia (Pleuractis) paumotensis Stutchbury. .

Fungia (Ctenactis) echinata (Pallas) "

Fungia (Verrillofungia) scabra Döderlein *

Fungia (Verrillofungia) concinna Verrill

Fungia (Danafungia) danai Milne-Edwards

\& Haime *

Fungia (Danafungia) horrida Dana. .

Fungia (Danafungia) spp

Fungia (Fungia) fungites (Linnaeus) ${ }^{*}$

Young Fungia spp.

Herpolitha Iimax (Houttuyn) *

Sandalolitha robusta (Quelch) "

Poritidae

Goniopora columna Dana .

Goniopora of duofasciata Thiel

Goniopora fruticulosa Saville-Kent

Goniopora cf. muscosa Wells" .

Goniopora somaliensis Vaughan"

Goniopora ct. tenuidens Quelch

Goniopora spp.

Porites australiensis Vaughan

Porites cf. australiensis Vaughan

Porites lichen Dana*

Porites cf. lichen Dana

Porites sp. 1 -

Porites spp.

Porites (Synaraea) sp. 1

Porites (Synaraea) sp. 2

Porites (Synaraea) sp. 3

Porites (Synaraea) sp. 4

Porites (Synaraea) sp. 5"

Porites (Synaraea) spp.

Alveopora excelsa Verrill

Faviidae

Favia favus (Forskaal)

Favia matthai Vaughan

Favia pallida (Dana)

Favia rotumana (Gardiner) "

Favia speciosa (Dana)

Favia stelligera (Dana)

Favia valenciennesi (Milne-Edwards \& Haime)

Faviaspp.

Favites abdita (Ellis \& Solander)

Favites chinensis (Verrill)

Favites complanata (Ehrenberg) ${ }^{\cdots}$

Favites halicora (Ehrenberg)

Favites pentagona (Esper)

Favites rotundata Veron \& Pichon

Favites russelli (Wells)

Favites spp.

Goniastrea australensis (Milne-Edwards

\& Haime)

Goniastrea edwardsi Chevalier" .

Goniastrea palauensis (Yabe \& Sugiyama)

Gonjastrea pectinata (Ehrenberg)

Goniastrea retiformis (Lamarck) *

Platygyra daedalea (Ellis \& Solander) *

Platygyra pini Chevalier *

Hydnophora exesa (Pallas)

Montastrea curta (Dana)

Plesiastrea versipora (Lamarck)

Leptastrea cf. bottae (Milne-Edwards \& Haime)

Leptastrea pruinosa Crossland

Leptastrea purpurea (Dana)
Podabacia crustacea (Pallas)

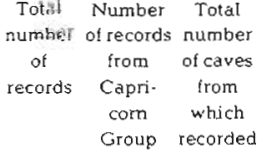

Group recorded

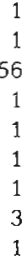

1
6
1
1
1
1
3
1
1
5
5
9
1
1
1

1

1

6

10

18

11

127

29

4
38

38

11

4

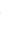

2

3

15

5

9

2

15

70

3

4

1

14

$\begin{array}{rr}0 & 1 \\ 0 & 1 \\ 1 & 39 \\ 0 & 1 \\ 0 & 1 \\ 0 & 1 \\ 0 & 1 \\ 0 & 3 \\ 0 & 1\end{array}$

1

5

15

1

11

11

$\begin{array}{ll}0 & 1\end{array}$

$\begin{array}{ll}0 & 1 \\ 0 & 1\end{array}$

12

$0 \quad 5$

07

212

$\begin{array}{rr}2 & 7 \\ 15 & 54\end{array}$

$0 \quad 13$

14

222

03

$\begin{array}{ll}0 & 7 \\ 0 & 4\end{array}$

0

$0 \quad 1$

01

04

06

01

05

$0 \quad 2$

12

$\begin{array}{ll}0 & 2\end{array}$

$0 \quad 2$

$\begin{array}{ll}0 & 1\end{array}$

0 2

o 10

$0 \quad 1$

113

04

0 1

246

01

13

0 2

0 1

310

$\begin{array}{ll}0 & 4\end{array}$

$\begin{array}{ll}0 & 1 \\ 0 & 2\end{array}$
313 
Leptastrea transversa Klunzinger Cyphastrea chalcidicum (Forskaal) Cyphastrea japonica Yabe \& Sugiyama Cyphastrea microphthalma (Lamarck) Cyphastrea serailia (Forskaal) Cyphastrea spp.

Echinopora gemmacea (Lamarck)" . Echinopora horrida Dana *

Echinopora lamellosa (Esper)

Echinopora mammiformis (Nemenzo)" * Young faviid

Oculinidae

Galaxea cf. astreata (Lamarck)

Galaxea fascicularis (Linnaeus) " .

Acrhelia hortescens (Dana) "

Merulinidae

Merulina ampliata (Ellis \& Solander)

Scapophyllia cylindrica (Milne-Edwards \& Haimel '.

Mussidae

Blastomussa wellsi Wijsman-Best

Blastomussa $\mathrm{sp}$

Cynarina lacrymalis (Milne-Edwards \& Haime)

Scolymia cf. vitiensis Brüggemann

Acanthastrea echinata (Dana)"

Acanthastrea sp."

Lobophyllia corymbosa (Forskaal) "

Lobophyllia hataii Yaba \& Sugiyama

Lobophyllia hemprichii (Ehrenberg)

Lobophyllia pachysepta Chevalier ${ }^{\circ}$

Lobophyllia spp.

Young mussid

Pectinidae

Echinophyllia aspera (Ellis \& Solander)

Echinophyllia orpheensis Veron \& Pichon

Oxypora lacera (Verrill)

Mycedium elephantotus (Pallas)

Pectinia alcicornis (Saville-Kent)

Pectinia paeonia (Dana)

Young Pectinia

Young pectiniid

Caryophylliidae

Euphylliasp.

Plerogysa sinuosa (Dana)

Physogyra lichtensteini (Milne-Edwards \& Haime)

Dendrophylliidae

Balanophyllia sp.

Dendrophyllia micrantha (Ehrenberg)

Tubastraea cf. aurea (Quoy \& Gaimard)

Turbinaria mesenterina (Lamarck) '

Turbinaria reniformis Bernard

Turbinaria stellulata (Lamarck) *

Turbinariaspp

- $75 \%$ or more of records from cave apertures

- Recorded from cave apertures only

Acknowledgements. I am very grateful to the following people for their advice or assistance during this research: Dr. $M$. Pichon, for his advice and encouragement as supervisor of my Ph. D. research; Mr. W. Nash, Mr. G. Dinesen, Mr. R. Moss, the crew of the R.V. 'James Kirby', and the staff of Lizard Island and Heron Island Research Stations, for assistance in the field; Dr. M. Pichon, Dr. J. Veron, Mr. H. Moll, and
Dr. C. Wallace, for assistance with identification of material; Dr. B. Chalker, for helpful discussion of the manuscript; the Drapers Company, London, for the research scholarship which allowed me to carry out this work; and the Great Barrier Reef Committee, for additional funds for field work.

\section{LITERATURE CITED}

Bak, R. P. M. (1976). The growth of coral colonies and the importance of crustose coralline algae and burrowing sponges in relation with carbonate accumulation. Neth. J. Sea. Res. 10: 285-337

Barnes, D. J. (1973). Growth in colonial scleractinians. Bull. mar. Sci. 23: 280-298

Barnes, D. J., Taylor, D. L., (1973). In situ studies of calcification and photosynthetic carbon fixation in the coral Montastrea annularis. Helgoländer wiss. Meeresunters. 24: 284-291

Barnes, J., Bellamy, D. J., Jones, D. J., Whitton, B. A., Drew, E. A., Kenyon, L., Lythgoe, J. N., Rosen, B. R. (1971) Morphology and ecology of the reef front of Aldabra. Symp. zool. Soc. Lond. 28: 87-114

Bassett-Smith, P. W. (1890). Report on the corals from the Tizard and Macclesfield Banks, China Sea. Ann. Mag. nat. Hist., Ser. 6, 6: 353-374

Bonem, R. M. (1977). Comparison of cavities and cryptic biota in modern reefs with those developed in lower Pennsylvanian (Morrowan) bioherms. In: Proceedings of the Third International Coral Reef Symposium, Vol. 1. University of Miami, Florida, pp. 75-80

Buddemeier, R. W., Kinzie, R. A. (1976). Coral growth. Oceanogr mar. Biol. A. Rev. 14: 183-225

Cuffey, R. J., Fonda, S. S. (1977). Cryptic bryozoan species assemblages in modern coral reefs off Andros and Eleuthera, Bahamas. In: Proceedings of the Third International Coral Reef Symposium, Vol. 1. University of Miami, Florida, pp. 81-86

Dinesen, Z. D. (1977). The coral fauna of the Chagos Archipelago. In: Proceedings of the Third International Coral Reef Symposium, Vol. 1. University of Miami, Florida, pp. 155-161

Dinesen, Z. D. (1980a). Some ecological aspects of coral assemblages in the Great Barrier Reef Province. Ph. D. thesis, James Cook University of North Queensland

Dinesen, Z. D. (1980b). A revision of the coral genus Leptoseris (Scleractinia: Fungiina: Agariciidae). Mem. Qd Mus. 20: 181-235

Dinesen, Z. D. (1982). Regional variation in shade-dwelling coral assemblages of the Great Barrier Reef Province. Mar. Ecol. Prog. Ser. 7: 117-123

Dustan, P. (1975). Growth and form in the reef coral Montastrea annularis. Mar. Biol. 33: 101-107

Gardiner, J. S. (1897). On some collections of corals of the family Pocilloporidae from the S. W. Pacific Ocean. Proc. zool. Soc. Lond.: 941-953

Gardiner, J. S. (1898). On the fungid corals collected by the author in the South Pacific. Proc. zool. Soc. Lond.: 525-539

Gardiner, J. S. (1904). Madreporaria. I. Introduction with notes on variation. II. Astreidae. In: Fauna and geography of the Maldives and Laccadives archipelagoes, Vol. 2. Cambridge University Press, Cambridge, pp. 756-790

Gardiner, J. S. (1905). Madreporaria. III. Fungida. IV. Turbinolidae. In: Fauna and geography of the Maldives and Laccadives archipelagoes, Vol. 2. Cambridge University Press, Cambridge, pp. 933-957 
Goreau, T. F. (1963). Calcium carbonate deposition by coralline algae and corals in relation to their roles as reef builders. Ann. N. Y. Acad. Sci. 109: 127-167

Graus, R. R. (1977). Investigation of coral growth adaptations using computer modelling. In: Proceedings of the Third International Coral Reef Symposium, Vol. 2. University of Miami, Florida, pp. 463-469

Graus, R. R., Macintyre, I. G. (1976). Light control of growth form in colonial reef corals. Science, N. Y. 193: 895-897

Hartman, W. D. (1973). Beneath Caribbean reefs. Discovery 9: $13-26$

Hartman, W. D. (1977). Sponges as reef builders and shapers. In: Frost, S. H., Weiss, M. P., Saunders, J. B. (eds.) Reefs and related carbonates - Ecology and sedimentology American Association of Petroleum Geologists, Tulsa, Oklahoma, pp. 127-134

Hartman, W. D., Goreau, T. F. (1970). Jamaican coralline sponges: their morphology, ecology and fossil relatives. Symp. zool. Soc. Lond. 25: 205-243

Highsmith, R. C. (1979). Coral growth rates and environmental control of density banding. J. exp. mar. Biol. Ecol. 37 $105-125$

Hoek, C. van den, Breeman, A. M., Bak, R. P. M., Buurt, G van (1978). The distribution of algae, corals and gorgonians in relation to depth, light attenuation, water movement and grazing pressure in the fringing coral reef of Curaçao, Netherlands Antilles. Aquat. Bot. 5: 1-46

Horst, C. J. van der (1921). The Madreporaria of the Siboga Expedition. II. Madreporaria Fungida. Siboga Exped. 16b: 53-98

Horst, C. J. van der (1922). Percy Sladen Trust Expedition to the Indian Ocean in 1905. IX. Madreporaria Agariciidae. Trans, Linn. Soc Lond., Ser. 2, 18: 417-429

Houck, J. E., Buddemeier, R. W., Smith, S, V., Jokiel, P. L. (1977). The response of coral growth rate and skeletal strontium to light intensity and water temperature. In: Proceedings of the Third International Coral Reef Symposium, Vol. 2. Univerity of Miami, Florida, pp. 425-431

Hughes, T P., Jackson, J. B. C. (1980). Do corals lie about their age? Some demographic consequences of partial mortality, fission and fusion. Science, N. Y. 209: 713-715

Jackson, J. B. C. (1977). Habitat area, colonization and development of epibenthic community structure. In: Keegan, B. F., Ceidigh, P. O., Boaden, P. J. S. (eds.) Biology of benthic organisms. 11th European Symposium on Marine Biology, Galway, Ireland, October 1976. Pergamon Press, Oxford, pp. 349-358

Jackson, J. B. C., Goreau, T. F., Hartman, W. D. (1971). Recent brachiopod-coralline sponge communities and their paleoecological significance. Science, N. Y. 173: 623-625

Jaubert, J. V. (1977). Light, metabolism and growth forms of the scleractinian coral Synaraea convexa Verrill in the lagoon of Moorea (French Polynesia). In: Proceedinngs of the Third International Coral Reef Symposium, Vol. 1. University of Miami, Florida, pp. 483-488

Jaubert, J. V., Vasseur, P. (1974). Light measurements: duration aspect and the distribution of benthic organisms in an Indian Ocean coral reef (Tuléar, Madagascar). In: Proceedings of the Second International Coral Reef Symposium, Vol. 2. Great Barrier Reef Committee, Brisbane, pp. $127-142$

Kawaguti, S. (1937). On the physiology of reef corals. I. On the oxygen exchange of reef corals. II. The effect of light on colour and form of reef corals. Palao. trop. biol. Stn Stud. 1: $187-208$

Laborel, J (1960). Contribution a l'étude directe des peuplements benthiques sciaphiles sur substrat rocheux en
Mediterranée. Recl Tray. Stn mar Endoume 33: 117-173

Lasker, H. R. (1977). Patterns of zooxanthellae distribution and polyp expansion in the reef coral Montastrea cavernosa. In: Proceedings of the Third International Coral Reef Symposium, Vol. 1. University of Miami, Florida, pp. $607-614$

Lewis, J. B. (1977). Suspension feeding in Atlantic reef corals and the importance of suspended particulate matter as a food source. In: Proceedings of the Third International Coral Reef Symposium, Vol. 1. University of Miami, Florida, pp. 405-408

Lewis, J. B., Price, W. S. (1975). Feeding mechanisms and feeding strategies of Atlantic reef corals. J. Zool. 176: $527-544$

Logan, A. (1977). Reef-dwelling articulate brachipods from Grand Cayman, B. W. I. In: Proceedings of the Third International Coral Reef Symposium, Vol. 1. University of Miami, Florida, pp. 87-93

Loya, Y. (1972). Community structure and species diversity of hermatypic corals at Eilat. Red Sea. Mar. Biol. 13: 100-123

Nie, N. H., Hull, C. H., Jenkins, J. G., Steinbrenner, K., Bent, D. H. (1975). SPSS. Statistical package for the social sciences, McGraw-Hill, New York

Noble, J. P. A., Logan, A., Webb, G. R. (1976). The recent Terebratulina community in the rocky subtidal zone of the Bay of Fundy, Canada. Lethaia 9: 1-17

Pérès, J. M., Picard, J. (1964). Nouveau manuel de bionomie benthique de la Mer Mediterranée. Recl Trav. Stn mar. Endoume 47: 5-137

Pichon, M. M. (1978). Recherches sur les peuplements à dominance d'anthozoaires dans les récifs coralliens de Tuléar (Madagascar). Atoll Res. Bull. 222: 1-447

Porter, J. W. (1976). Autotrophy, heterotrophy and resource partitioning in Caribbean reef-building corals. Am. Nat. 110: 731-742

Pouliquen, L. (1969). Remarques sur la présence d'éponges de I'étage bathyal dans les grottes sous-marines obscures de Mediterranée. C. R. Acad. Sci. Paris 268: 1324-1326

Pouliquen, L. (1971 (1972)). Les spongiaires des grottes sousmarines de la région de Marseille: Ecologie et systématique. Téthys 3:717-758

Quelch, J. J. (1886). Report on the reef-corals. Rep. Sci. Results Voyage H. M. S. Challenger Zool. 16: 1-203

Roos, P. J. (1967). Growth and occurrence of the reef coral Porites astreoides Lamarck in relation to submarine irradiance distribution, Drukkerij Elinkwijk, Utrecht

Rosen, B. R. (1971). The distribution of reef coral genera in the Indian Ocean. Symp. zool. Soc. Lond. 28: 263-299

Scatterday, J. W. (1974). Reefs and associated coral assembIages off Bonaire, Netherlands Antilles, and their bearing on Pleistocene and Recent reef models. In: Proceedings of the Second International Coral Reef Symposium, Vol. 2. Great Barrier Reef Comittee, Brisbane, pp. 85-106

Sheppard, C. R. C. (1980). Coral cover, zonation and diversity on reef slopes of Chagos Atolls, and population structures of the major species. Mar. Ecol. Prog. Ser. 2: 193-205

Titlyanov, E. A, Shaposhnikova, M. G., Zvalinskii, V I. (1980). Photosynthesis and adaptation of corals to irradiance. 1. Contents and native state of photosynthetic pigments in symbiotic microalga. Photosynthetica 14: $413-421$

Vacelet, J. (1967a). Quelques éponges pharétronides et 'silico-calcaires' de grottes sousmarines obscures. Recl Trav. Stn mar Endoume 58 (Bull. 42): 121-132

Vacelet, J. (1967b). Descriptions d'éponges pharétronides actuelles des tunnels obscurs sousrécifaux de Tuléar ( $\mathrm{Ma}$ dagascar). Recl Trav. Stn mar. Endoume 6 (Suppl.): 36-62 
Vacelet, J., Vasseur, P. (1977). Sponge distribution in coral reefs and related areas in the vicinity of Tuléar (Madagascar). In: Proceedings of the Third International Coral Reef Symposium, Vol. 1. University of Miami, Florida, pp. 113-118

Vasseur, P. (1974). The overhangs, tunnels and dark reef galleries of Tuléar (Madagascar) and their sessile invertebrate communities. In: Proceedings of the Second International Coral Reef Symposium, Vol. 2. Great Barrier Reef Committee, Brisbane, pp. 143-159

Vasseur, P. (1977). Cryptic sessile communities in various coral formations on reef flats in the Tuléar vicinity (Madagascar). In: Proceedings of the Third International Coral Reef Symposium, Vol. 1. University of Miami, Florida, pp. 95-100

Vaughan, T. W. (1907). Recent Madreporaria of the Hawaiian Islands and Laysan. Bull. U.S. natn. Mus. 59: 1-427

Vaughan, T. W., Wells, J. W. (1943). Revision of the suborders, families and genera of the Scleractinia. Spec. Pap. geol. Soc. Am. 448: 1-363

Veron, J. E. N., Pichon, M. M. (1976). Scleractinia of Eastern Australia. I. Families Thamnasteriidae, Astrocoeniidae, Pocilloporidae. Aust. Inst. mar. Sci. Monogr. Ser. 1: 1-86

Veron, J. E. N., Pichon, M. M. (1980). Scleractinia of Eastern Australia. III. Families Agariciidae, Siderastreidae, Fungiidae, Oculinidae, Merulinidae, Mussidae, Pectiniidae, Caryophylliidae, Dendrophylliidae. Aust. Inst. mar. Sci. Monogr. Ser. 4: 1-422

Veron, J. E. N., Pichon, M. M., Wijsman-Best, M. (1977). Scleractinia of Eastem Australia. II. Families Faviidae, Trachyphyllidae. Aust. Inst. mar. Sci. Monogr. Ser. 3: $1-233$
Wallace, C. C. (1978). The coral genus Acropora (Scleractinia: Astrocoeniina: Acroporidae) in the central and southern Great Barrier Reef Province. Mem. Qd Mus. 18: 273-319

Wells, J. W. (1954). Recent corals of the Marshall Islands. U. S. geol. Surv. 260-1: 385-486

Wells, J. W. (1955). A survey of the distribution of reef coral genera in the Great Barrier Reef Province. Rep. Gt Barrier Reef Comm. 6: 21-29

Wells, J. W. (1956). Scleractinia. In: Moore, R. C. (ed.) Treatise on invertebrate paleontology, Part $F$, Coelenterata. Geological Society of America, and University of Kansas, Boulder, Colorado, and Lawrence, Kansas, pp. F 328-478

Wethey, D. S., Porter, J. W. (1976a). 'Sun' and 'shade' differences in productivity of reef corals. Nature, Lond. 262: 281-282

Wethey, D. S., Porter, J. W. (1976b). Habitat-related patterns of productivity of the foliaceous reef coral, Pavona praetorta Dana. In: Mackie, G. O. (ed.) Coelenterate ecology and behavior. Plenum Press, New York, pp. 59-66

Wijsman-Best, M. (1973). A new species of the Pacific coral genus Blastomussa from New Caledonia. Pacif. Sci. 27: $154-155$

Wijsman-Best, M. (1974). Habitat-induced modification of reef corals (Faviidae) and its consequences for taxonomy. In: Proceedings of the Second International Coral Reef Symposium, Vol. 2. Great Barrier Reef Committee, Brisbane, pp. 217-228

Zvalinskii, V I., Leletkin, V. A., Titlyanov, E. A., Shaposhnikova, M. G. (1980). Photosynthesis and adaptation of corals to irradiance. 2. Oxygen exchange. Photosynthetica 14: $422-430$ 